\title{
THE LADINS AND THEIR HISTORY OF LEGAL RESILIENCE
}

\author{
I LADINI E LA LORO STORIA DI RESILIENZA LEGALE
}

\author{
José Rafael Gómez Biamón
}

\section{Ph.D. from Centro de Estudios Avanzados de Puerto Rico y el Caribe}

\begin{abstract}
English: The Ladins of Trentino-Alto Adige/Südtirol are an ethnic minority with an ancient history, located in the Dolomites Mountains, a place associated with extreme beauty and rugged land. Under the Italian Constitution, Ladins have acquired several legal rights connected with their language and history.

Ladins have a history dating to the Roman Empire. Located in a strategic place, with Alpine valleys and mountain paths that connect the Italian Peninsula with Central Europe, several Germanic tribes after the end of the Roman Empire invaded and established themselves in the zone, enforcing their customs and laws. Those so-called "barbaric laws" together with Carolingian and Ecclesiastical law gave birth to a particular system of law during the Middle Ages.

Afterward, Ladins became part of the Holy Roman Empire, and later, part of the House of Habsburg. During the aftermath of World War I, Italy obtained the region from the Austrian-Hungarian Empire in the peace treaty of Saint Germain-en-Laye of 1919.

The Italian experience with the Ladins started soon after World War I with several publications taking the task of understanding the origins of their language and its people. Ever since, Italian interest in the Ladins has not ceased. In 1998 the Italian Constitutional Court recognized the Ladin people their right to be represented in regional institutions, answering to the historical and social reality of Alto Adige/Südtirol.

Consequently, the legal resilience of the Ladins gives testimony of a long history of peaceful victories for their rights, associated with the Ladin language, in the context of judicial procedures, political participation, and legislation.

In comparison, Ladins living in other regions of Italy like Veneto and Friuli Venezia Giulia have not reached the same level of autonomy and privileges as those in Trentino-Alto Adige/Südtirol.
\end{abstract}

Keywords: Trentino-Alto Adige/Südtirol; South Tyrol; Ladin; Minority Rights; Medieval Criminal Law and Procedure; Italian Constitutional Law; Autonomy.

Abstract Italiano: I Ladini del Trentino-Alto Adige/Südtirol sono una minoranza etnica con una storia antica sviluppatasi sulle Dolomiti, una terra selvaggia dalla bellezza straordinaria. In accordo con la Costituzione italiana, i Ladini hanno acquisito diversi diritti collegati alla loro lingua e alla loro storia.

La storia ladina ha inizio in epoca romana imperiale: localizzati in posti strategici, tra vallate alpine e valichi di montagna che collegano la penisola italiana all'Europa centrale,

* Italian Review of Legal History, 7 (2021), n. 9, pagg. 295-322

* https://riviste.unimi.it/index.php/irlh/index

* ISSN 2464-8914 - DOI 10.54103/2464-8914/16891. Articolo pubblicato sotto Licenza CC-BY. 
diversi popoli germanici, dopo la fine dell'Impero Romano, invasero la zona e lì si stabilirono, imponendo le loro usanze e le loro leggi. Le cosiddette 'leggi barbariche', insieme alle leggi carolingia ed ecclesiastica, diedero vita a un particolare sistema legale durante il Medioevo.

In seguito i ladini divennero parte del Sacro Romano Impero e successivamente della casa d'Asburgo. Conseguentemente alla prima guerra mondiale, I'Italia ottenne la regione dall'Impero Austroungarico nel trattato di pace di Saint Germain-en-Laye del 1919.

L'esperienza italiana con i ladini iniziò poco dopo la fine della prima guerra mondiale, con diverse pubblicazioni atte a comprenderne le origini della lingua e del popolo in generale. Da allora l'interesse per i Ladini non è più cessato. Nel 1998 la Corte Costituzionale ha riconosciuto al popolo ladino il diritto ad essere rappresentato in istituzioni regionali, rispondendo alla realtà storica e sociale dell'Alto Adige/Südtirol.

La resilienza legale dei Ladini testimonia quindi una lunga storia di vittorie pacifiche per $\mathrm{i}$ loro diritti associati alla loro lingua, in un contesto di procedure giuridiche, partecipazione politica e legislazione.

In confronto a quelli del Trentino-Alto Adige/Südtirol, i Ladini residenti in altre regioni, quali ad esempio Friuli Venezia Giulia e Veneto, non hanno tuttavia raggiunto pari livelli di autonomia e di privilegi.

Parole chiave: Trentino-Alto Adige/Südtirol; ladini; minoranze linguistiche; processo penale medievale; diritto costituzionale; autonomia.

Table of contents: 1. Ladins ancient historical context. - 1.1. Ladin medieval legal history. -2. Ladins in the context of revolution and wars (1797-1947). - 3. Constitutional Reforms and Autonomy for Ladins in Trentino-Alto-Adige/Südtirol. - 4. Conclusions.

\section{Ladins ancient historical context}

The Ladin community of Trentino-Alto Adige/Südtirol ${ }^{1}$, located in northeast Italy, has a bimillenary history dating back to pre-Roman times. Before the annexation to Italy through the Treaty of Saint Germain-en-Laye of 1919, they were part of Austria and before that with County of Tyrol in the Holy Roman Empire, with a brief period of Bavarian rule during the Napoleonic period.

During the pre-Roman period, the people who lived in current Ladin valleys had intense contact with other groups living in the Alps; proof of this is found in very particular ceramic work recovered in archeological sites ${ }^{2}$. As Romans pushed north of the Italian Peninsula, they named the people they encountered in the Alps Rhaetian. Henceforth, Romanization started with some Rhaetian learning Latin because of contact with Romans through trade. Also, some worked as

\footnotetext{
${ }^{1}$ Alto Adige/Südtirol is the official name of the most northern province of Italy. It is also known in English literature and historiography by the name of South Tirol or South Tyrol. For the purposes of this article, official bilingual names in Italian and German are used.

${ }^{2}$ Richebuono, 1992, p. 7.
} 
slaves building roads and transporting merchandise, becoming bilingual. During the year 15 AD Roman emperor Tiberius and Nero Claudius Drusus advanced legions into the territory until they reached the confine of the Danube River to the north. To stop the Roman conquest, an alliance of numerous Alpine tribes was formed without success. Rome's interest in the Alpine zone was not to stop the flow of northerners coming into Italy, but instead, it was established that it was indispensable for the military and economic control of Eastern Central Europe ${ }^{3}$. The first Rhaetian group to accept the conquest was the Anuanes from the Val di Non, becoming Roman citizens in 46 AD with Emperor Claudius 4 .

The conquest of Rhaetia was the work of Tiberius and Drusus. Drusus marched with two armies from the south to the north passing through the Val d'Adige/ Etschtal. Another army with Tiberius marched from west to east, using Lake Constance as a transportation base for the invasion. Even though there is little known about this period, Roman sources tell how early Rhaetian were fond of their independence and fought for their liberty 5 . The arrival of the Romans was a tragic period having their best men killed and deported, their villages burned, and losing their independence. Eventually, the conquered territory was named Roman Province of Rhaetia with Val Badia/Gadertal forming part of the Roman Province of Noricum to the East.

During the reign of Constantine as Roman emperor (306-337), the Alps were probably not Christianized yet. There is little documentation about this period, but there is consensus among historians that Christianization happened during the Roman period ${ }^{6}$. The first missionaries to both the provinces of Rhaetia and Noricum came from Aquileia, after the first half of the 5th Century. Aquileia became the principal center of Christian flow into the Dolomites, even though other Christian cedes were also formed, like Trento ${ }^{7}$. Consequently, Christianization came progressively with the first churches built during the years 500-600. Eventually, missionaries arriving from the port of Aquileia established the dioceses of Sabiona/Säben in current Trentino Alto-Adige/Südtirol which for more than 1000 years included all Ladin valleys. The Catholic Church used Latin as its main language, hence contributing notably to the Romanization of the area and its population. Afterward, the dioceses were transferred to nearby Bressanone/Brixen and incorporated to Salzburg. During this later period, the Holy Roman Empire established the ecclesiastical principality of Brixen/Bressanone and the County of Tyrol, imposing their administrative and legal structure in the German language on the Ladins.

\footnotetext{
${ }^{3}$ Belardi, 2003, p. 10.

${ }^{4}$ Richebuono, 1992, p. 14.

${ }^{5}$ Ibid, 10

${ }^{6}$ Ibid, 13

${ }^{7}$ Pescosta, 2010, p. 68.
} 


\subsection{Ladin Medieval Legal History}

With the fall of the Western Roman Empire, from 476 until almost one century later, the Alpine territory was without government. During that period there was a situation of anarchy where the inhabitants organized in autonomous communities, maintaining their own ancient customs and mixing them with Roman law 8 . After 568 the Lombards occupied Aquileia, establishing the Duchy of Friuli and extended their dominion into the Dolomites reaching Ampezzo and Rocca Pietore. They also expanded to Bolzano/Bozen through the Adige/Edge Valley and established the Duchy of Trento. Lombards are credited with raising the population of the Ladin valleys that became depopulated after the fall of the Empire ${ }^{9}$. With peace and prosperity relations between the Lombards and the Roman-Rhaetian population in the Adige/Edge Valley grew ${ }^{10}$.

In contrast to Roman law, Lombard law established the obligation to defend the territory with arms. Pastures and forests became collective and indivisible with certain families and land titles transmitted to their resident male sons. The most notable law created by the Lombards was the so-called Edict of Rothari in 643. The Rothari was a consolidation of different Lombard laws and customs ${ }^{11}$. It was written in Latin and gave a written testimony of the existing customs during that time and established a new form of government ${ }^{12}$. Even though it was written in Latin, it varied significantly with Roman law, which was still in use by the Romanized population ${ }^{13}$. Furthermore, many of the legal principles of the Rothari have criminal law importance in trying to stop or contain a very violent society ${ }^{14}$. It introduced compensations for an offended party and his family by the person found guilty of a crime. It was also different from Roman law in cases of adultery, rape, and physical violence ${ }^{15}$. The Lombards left some traces of their legal system in the Dolomites valleys of Val di Fiemme/Fleimstal, Valle di Cadore, and Valle d'Ampezzo. Even though Lombards had a Germanic language, it did not pose a threat to the Rhaetic-Latin language because they were much Romanized and were few in numbers ${ }^{16}$.

During the 6th and 7th Centuries, Bavarians and Franks, both Germanic groups, entered Trentino-Alto Adige/Südtirol leaving a notable and permanent mark in the region. Around 575 an army of Franks under the leader Charemnichs entered the territory from what is now Switzerland through Vatellina and got their army

\footnotetext{
${ }^{8}$ Ibid, 64

${ }^{9}$ Ibid.

${ }^{10}$ Hodgkin, 1895, pp. 33-34.

${ }^{11}$ Diurni, 2011, p. 90.

12 Ibid.

${ }^{13}$ Astuti, 1968, p. 69.

${ }^{14}$ Pene Vidari, 2009, p. 39.

${ }^{15}$ Astuti, 1968, p. 91.

${ }^{16}$ Richebuono, 1992, pp. 19-20.
} 
to Val di Non/Nonstal through the Passo del Tonale. Arriving at Trento they met the Lombards and plundered the city ${ }^{17}$. Euin the Lombard Duke of Trento met Charemnichs in battle at Salorno/Salurn beating the Franks and slaying Charemnichs and his allies, thus recovering the territory from the Frank invaders ${ }^{18}$. To protect the zone, Lombards extended their territory to Merano/Meran and the important Val d'Isarco/Eisacktal ${ }^{19}$. In 590 the Franks sent another army to fight the Lombards lead by Duke Cedinus, weakening Lombard control of the region. Around the year 600, Bavarians came down from Renon/Ritten and started to conquer the scarcely populated territory of what now is Alto Adige/Südtirol with no notable opposition ${ }^{20}$.

Even though encounters between Lombards and Bavarians were very violent, eventually the Roman-Rhaetian population accepted their new conquerors. An important difference between the two groups was that Bavarians were farmers; therefore, they established new farms and agricultural methods in the territory, some of which are still in use. Bavarian rule was characterized by a constant arrival of reinforcements from north of the Alps. Different from Lombards, Bavarians were not Romanized; therefore, they are credited with the first Germanization of the Roman-Rhaetian residents in current Trentino Alto-Adige/Südtirol. In order to defend their territory from Slav groups coming from the east, Bavarians pushed to Val Pusteria/Pusterta ${ }^{21}$. By the early 8 th Century they had extended their domain to most of current Alto Adige/Südtirol, including the cities of Bolzano/Bozen and Merano/Meran, with the exception of a minority of Roman-Rhaetian in more remote locations: the Ladins living in Val Gardena/Gröden, Valle d'Ampezzo, Val Badia/Gadertal, Val Venosta/Vinschgau, and Val di Fiemme.

Later in $\mathbf{7 7 4}$ the Franks under the rule of Charlemagne won against the Lombards in Pavia and took their kingdom, incorporating their lands into their empire. Subsequently, in 788, the Bavarians were defeated by the Franks; thus, their entire domain came into Frankish rule. Even under Frankish rule, from a legal perspective, the area later called Tyrol became more like Bavaria whereas Trento was more Lombard ${ }^{22}$. Even after the so-called Carolingian reorganization of the old Roman Empire the old Corte Regia of Lombard origin remained, giving to local nobles a strong sense of independence and rights ${ }^{23}$. In reality when the Franks took control of current Trentino-Alto Adige/Südtirol, Bavaria and Italy were both thriving sophisticated regions, thus the Franks incorporated some of their cus-

\footnotetext{
${ }^{17}$ De Biasi, 2008, p. 14.

${ }^{18}$ Hodgkin, 1895, pp.27-28.

${ }^{19}$ Kustatscher, 2010, p. 62.

${ }^{20}$ Pescosta, 2010, p. 65.

${ }^{21}$ Kustatscher, 2010, p. 64.

22 Ibid, 67.

${ }^{23}$ Pescosta, 2010, p. 66.
} 
toms into their rule ${ }^{24}$. An important change occurred when in 798 the diocese of Sabiona changed from Aquileia to Salzburg, marking the Christianization of the Alps in present Alto Adige/Südtirol in the German language. Nevertheless, because of lack of historical documentation until the 10th Century, little is known about the colonization of the Dolomites and the Ladin valleys during the High Middle Ages ${ }^{25}$.

Henceforth, the Carolingian Empire emerged with a tradition of military expansion and coercive Christianization of pagans. With the increased power of Frankish rulers in North and Central Italy the introduction of new symbolic elements served the practical need of communicating with Italian subjects, who were used to the late Roman and early Byzantine language of authority ${ }^{26}$. After 798 when the Dioceses of Sabiona distanced from Aquileia, there was an economic and social change in the Dolomites. Dioceses and monasteries got more power thanks to generous donations of territories from the dukes, counts, kings, and emperors. Most notably, in 845 Louis II, Emperor of the Carolingian Empire, gave immunity to the bishop of Sabiona, making him autonomous. Thus, the property of the dioceses grew progressively ${ }^{27}$.

With the division of the Carolingian Empire, current Trentino-Alto Adige/Südtirol was divided from the Duchy of Trento, probably including the right side of the Adige/Etsch River up to Merano/Meran entering the newly created Italian Kingdom and with the valleys of Val Venosta/Vinschgau, Val d'Isarco/Eisacktal, Val Pusteria/Pustertal, and the Inn Valley into the also newly created Kingdom of Germany ${ }^{28}$. The result was that the Ladin valleys entered the jurisdiction of the Kingdom of Germany.

The context in which Frankish law developed in the Alpine region was characterized by a hostile world and an unpredictable fate. All signs of a fragile economy were present, employing simple techniques and a rudimentary political system that was fragmented by the loss of Roman colonial controls. One example of this was how suspicious strangers could be killed on sight, if presumed as thieves and failing to justify their arrival ${ }^{29}$. Historian Elizabeth Mayer-Marthaler has done some notable work on the legal history of the Grisons, the most eastern part of current Switzerland. She was concerned with the constitutional status of Rhaetia with the Frankish reality underlying the Roman apparencies in matters of public law and administrative law that is well illustrated in the Lex Romana Curiensis ${ }^{30}$. Another medieval legal document that signal how eastern Frankish law pene-

\footnotetext{
${ }^{24}$ Davis, 2005, p. 243.

${ }^{25}$ Pescosta, 2010, p. 72.

${ }^{26}$ Garipzanov, 2008, p. 40.

${ }^{27}$ Pescosta, 2010, p. 73.

${ }^{28}$ Kustatscher, 2010, p. 69.

${ }^{29}$ Coleman, 1974, p. 574.

${ }^{30}$ H.S.O., 1951, p. 129.
} 
trated the Alpine region is the Lex Romana Utinensis ${ }^{31}$. Both the Lex Romana Curiensis and the Lex Romana Utinensis include similarities and are based mostly in Roman law, including some laws and customs from the different Germanic populations that penetrated Italy. It is also important to mention that the differences between Germanic and Roman law are not only with regards to regulations of private law, but for example, in fundamental things like the legal concept of what is a legal person ${ }^{32}$. These laws were transplanted into the existing Roman law, leaving an important trace ${ }^{33}$. Therefore, the insertion of the Carolingian period did not mutate the Lombard structure of the judicial procedure, but introduced a more coherent and incessive decisional power of their judges ${ }^{34}$. Consequently, in the Italian peninsula a strong Lombard tradition together with the Latin persisted even after the Franks invaded because they remained mostly north of the Alps, moving some elite military groups to command the south ${ }^{35}$. Nonetheless, there is controversy with regards to Carolingian influence in Italy. Some writers tend to support the idea that Italy gradually became more Frankish in the development of law, while others downplay the Carolingian takeover of Italy, arguing that the incorporation of Italy in the Frankish European context had little effect ${ }^{36}$. In reality, Charlemagne's efforts in ruling new places did not necessarily entail trying to insist on uniformity. Instead, Charlamagne learned from the conquered regions, including France ${ }^{37}$. Furthermore, the Carolingian political system was flexible enough to survive numerous territorial partitions and to accommodate a variety of identities under Frankish law ${ }^{38}$. Eventually, Carolingian legislation for Italy was incorporated into Italian legal tradition, appearing alongside the legal compilation of the Lombard kings in the Liber Paiensis from $1040^{39}$.

When Otto I became Emperor of the Holy Roman Empire in 962, he reunified all the Empire, but it was very different than when Charlamagne was emperor $^{40}$. The Empire did not include France, which from 987 would be treated as a different kingdom under the House of Capet. When Otto I reunified all the Holy Roman Empire Ladins were under the reign of a German-speaking ruler. Specifically, with the organization of the principi vescovi the Inn Valley, the Isarco/Eisack Valley, and then Val Pusteria/Pustertal were given to the principality of Bressanone/Brixen to protect the movement of the Holy Emperor to Italy through those

\footnotetext{
${ }^{31}$ Dean, 1997, p. 9.

${ }^{32}$ Astuti, 1968, p. 80.

${ }^{33}$ Tammaro, 2018, p. 227.

${ }^{34}$ Diurni, 2011, p. 102.

${ }^{35}$ Pene Vidari, 2009, p. 40.

${ }^{36}$ Davis, 2005, p. 243.

${ }^{37}$ Ibid., p. 242.

${ }^{38}$ Maclean, 2009, p. 2.

${ }^{39}$ Davis, 2005, p. 278.

${ }^{40}$ De Biasi, 2008, p. 17.
} 
valleys, among other reasons. Most notably, in 1004 Emperor Enrico II donated the County of Trento with Val di Fiemme/Flaimstol. Afterward, in 1027 Emperor Conrad gave the County of Bolzano and Val Venosta/Vinschgau to the Bishop of Trento, including the Inn Valley, the Isarco/Eisack, which included Val Gardena/ Gröden to the Bishop of Bressanone/Brixen and Val Badia/Gadertal. The County of Bolzano/Bozen and Val Venosta were incorporated to Trento. Both princes and bishops from Trento and Brixen/Bressanone were limited in their power to the Holy Roman Empire and remained in command until $1803^{41}$. Hereafter, Tyrol was unified by Count Meinhard II, and a few years later the new county was consolidated and constructed officially as a state in 1282 by King Rudolf I of Germany, from the house of Habsburg. In 1335 Henry of Bohemia, Count of Tyrol died leaving control of Tyrol to his daughter Countess Margaret, who married John Henry of Luxemburg, passing Tyrol to the powerful House of Luxemburg. Regardless, in 1363 after a bloody power play, Tyrol passed to Rudolf IV, Duke of Austria from the House of Habsburg using a contract of inheritance with Countess Margaret. Rudolf IV was brother to Margaret's sister-in-law, who was a widow. Henceforth, Trentino Alto-Adige/Südtirol remained mostly under Austrian rule until it was ceded to Italy with the Treaty of Saint Germain-en-Laye of 1919.

In contrast, the Holy Roman Empire was more flexible and inclusive to other languages and groups, not like the Franks who were more centralized ${ }^{42}$. Nevertheless, Latin was the only elite language used, and it transcended all other vernacular dialects. Together with Roman Catholicism, Latin developed a common belief system, and most importantly a language required to discuss morality, justice, and politics ${ }^{43}$. Accordingly, the power of the Church of Trento and SabionaBressanone grew notably because Otto I needed complete control of the Alps passes towards Italy; therefore, he gave lands to the Church and at the same time resolved the issue of land inheritances because Church members had no successors.

With regards to the population of current Trentino-Alto Adige/Südtirol, the Roman-Rhaetian element had no option than to live with their new masters, whether Lombards, Bavarian or Franks, in a relationship that in the beginning was separate, but eventually it became more mixed. In the western central Alps, from the Grisons until Friuli, the vulgar Latin language was very similar to the point that several linguists have indicated the evolution of a new language, the Rhaeto-Romance, Romansch, or Ladin ${ }^{44}$. Therefore, Ladins under the Holy Roman Empire became part of an empire that was not conceived as a unitary state with a homogeneous population, but instead a diversity of lands and people under

\footnotetext{
${ }^{41}$ Ibid., p. 14.

${ }^{42}$ Wilson, 2017, p. 234.

${ }^{43}$ Ibid.

${ }^{44}$ Kustatscher, 2010, p. 68.
} 
imperial jurisdiction ${ }^{45}$. For German Emperors, what made them worthy of their title was precisely the power to rule extensive lands and different peoples. Historian Peter Wilson distinguishes that even with great socio-economic differences in Europe during the Middle Ages, there were no fundamental divisions between ethnic groups, such as those seen in other populations like in Russia or China ${ }^{46}$. This fact undoubtedly helped the Ladins retain their language and culture. Eventually, the Ladin language disappeared in the Vorarlberg, now western Austria, but it survived in Rhaetia.

An intensive colonization of Ladin territory in Tyrol took place from 950 to 1250 characterized by using all available land for agriculture and adopting a system of single farms units ${ }^{47}$. Colonization was done mostly by local Ladins living in the area. An interesting fact is that the word Tyrol has a Ladin language etymology. The first document written in Ladin is found in a poem of 24 verses written in Ampezzano, a Ladin dialect, dating to $1568^{48}$. Later in 1632 , there is an official proclamation from the Catholic Church and in 1703 another proclamation calling Ladin men to arms, all written in the Ladin language. The Alpine Valleys of the Inn River, the Isarco/Eisack River, and the Adige/Etsch River continued to be a route frequently used by Holy Roman Emperors traveling to Italy, hence conserving Tyrol's role within the Holy Roman Empire as an important strategic place for commerce and military control of Central Europe as ancient Romans had previously established.

In early medieval Europe, communities that had a tribal sense were vastly different from ours. This cannot be ignored because it brings forth a context of the so-called "barbaric law" that continued to influence the order of things into and beyond the Middle Ages, ${ }^{49}$ as can be seen in how within a judicial procedure, the family structure remained fundamental. This was more evident in legal traditions founded with unwritten rules and procedures. Hence, a natural justice system, both in civil and criminal law, was centered in the so-called faida by which the judicial procedure involved a single person and their respective family ${ }^{50}$. During the first centuries of the Holy Roman Empire, when a legal controversy needed to be resolved or a new town needed to be founded, public legal procedures or so-called trials were held officially in the German language and under an old oak tree, following the ancient Germanic custom. Later they were held inside houses or in palaces. In those early years there was a lack of printed laws, legal norms, and no case transcript existed. Therefore, the language used in the procedure was the spoken word; verbal participation carefully regulated and mutually de-

\footnotetext{
${ }^{45}$ Ibid., 179.

${ }^{46}$ Wilson, 2017, p. 235.

${ }^{47}$ Richebuono, 1992, p. 34.

${ }^{48}$ Bernardi, 2002, pp. 44-45.

${ }^{49}$ Coleman, 1974, p. 573.

${ }^{50}$ Galgani, 2012, p. 27.
} 
marcated with both peasants and lords with legitimate share ${ }^{51}$.

In reality, law and judicial procedures during the Middle Ages were structured in what could be called ascertainable principles ${ }^{52}$. Criminal judicial processes were characterized by the judicial inquest, a simple method of gathering information from the local population, and a way of having an incident, such as, murders or theft announced to a governing power so that such crimes be prosecuted ${ }^{53}$. The majority of civil and criminal cases were settled by oath-swearing and the number of oath helpers was important depending on the circumstances, since every free person was enrolled in a pledge group responsible for his well-being. Consequently, denial of support from the pledge group was equivalent to an advanced guilty verdict. Therefore, the oath was the primary mode of gathering evidence, not responding necessarily to the truth of a specific fact but rather to justify a claim or a defense, depending on the case ${ }^{54}$.

Consequently, the so-called judicial inquest of the Middle Ages criminal procedures has a strong influence deriving from Germanic law. The Carolingian Capitularies seem to assume the possibility of a judicial inquest, when in a judicial procedure local people could be used as witness chosen by those sitting in judgement $^{55}$. In spite of that, in the Carolingian Capitularies there is nothing specifically setting rules for either the judicial inquest or testimonies; and furthermore, the judicial inquest was a way of exerting royal control that came after the Carolingian period ${ }^{56}$. In comparison with Bavarian law, an examination of the witness by the court before the oath swearing was preferred. Also, the so-called Bavarian Code and then in the Lex Alamannorum gave priority to court investigations, the former warning against an easily reliance upon oath-swearing to terminate a case ${ }^{57}$. The procedure was done asking questions and responding to them ${ }^{58}$. Whereas in medieval law, when a confession was obtained from the accused, the fact was considered notorious and manifest, requiring only additional clues for a conviction. Therefore, confessions were highly valuable, and even though they had to be done with all the necessary legal formalities, they reduced the time of a criminal investigation to a minimum, being only valid when made by an adult before their adversary ${ }^{59}$.

Furthermore, regarding the origin of judicial inquest, it should be emphasized that a system of swearing to the truth of an event, the so-called sacramentales,

\footnotetext{
51 Toch, 1986, p. 681.

${ }^{52}$ Coleman, 1974, p. 577.

${ }^{53}$ Davis, 2005, p. 260.

${ }^{54}$ Coleman, 1974, p. 576.

${ }^{55}$ Davis, 2005, p. 264.

${ }^{56}$ Ibid., 266.

${ }^{57}$ Coleman, 1974, p. 579.

${ }^{58}$ Diurni, 2011, p. 89.

${ }^{59}$ Foucault, 199, pp. 38-39.
} 
were also used in the Lombard's, Frisian's, and Bavarian legal codes, swearing to the truth of a fact or the falsehood of a criminal accusation ${ }^{60}$. Solemn oaths were done either upon a Bible or their weapons consecrated by a Christian priest, asserting to the belief in the truth of their statement. The value of the truth was highly valued and was an old pagan virtue. Whereas one party of the controversy yielded to the force of the evidence presented and therefore, admitted that either the plaintiff had failed to make good his attack, or the defendant his defence. When this happened, one side of the legal controversy and his supporters expressed that they no longer dared to swear to the truth, having to pay or renounce their claim ${ }^{61}$. All this led to caution from the population when speaking in a judicial inquest to avoid verbal commitment, as one Tyrolean peasant during a criminal procedure in 1327, explained to the court: «If I talk too much, let it not be to my prejudice ${ }^{62}$.

Furthermore, it was also common to follow the established legal procedural requirements and also follow one's own law, asserting to local claims of family and region. These policies were not aiming to rework how power was exercised locally, but instead they aimed at reworking the ultimate goal of how local power related to the central power ${ }^{63}$. Therefore, initially a duality in the applicability of laws existed when Germanic law entered in conflict with Roman law, determined not by the place where a person lived, but instead by their ethnicity. In other words, the law that applied was personal and not territorial ${ }^{64}$. Nonetheless, this view is not universally accepted among historians, and another explanation is that Germanic law applied to the entire population, with Roman law applying only in learned circles and not necessarily in all judicial procedures. The Ladin language was used in court procedure form the early 9th century from Saint-Gall, now western Switzerland, run by Duke Hunfrid during the Carolingian Empire. Hunfrid interrogated the witness, gave evidence in a land barrier case, and ordered judges to make findings in Ladin ${ }^{65}$. In a latter judicial case of 1327, a man by the name of Schöneck was criminally tried, and several witness that only spoke Ladin were allowed to testify in their own language ${ }^{66}$. Criminal procedures were more complicated in the sense that the trials were held under the personal law of the accused. Even though the penalty for the crime should be under the same law, the private part of the sentence; for example, payment for the grievances to the offended party were established according their own personal law. For example, if a Roman was accused of a crime against another Roman, the penal

\footnotetext{
${ }^{60}$ Hodgkin, 1895, pp.224-225.

61 lbid.

62 Toch, 1986, p. 675.

${ }^{63}$ Davis, 2005, p. 172.

${ }^{64}$ Barnwell, 2000, pp. 7-8.

${ }^{65}$ Davis, 2005, p. 65.

${ }^{66}$ Pescosta, 2010, p. 101.
} 
and criminal procedure used would be Roman law ${ }^{67}$.

Another form of criminal procedures during the Middle Ages was carried out by the Catholic Church. After the so-called "Barbarian" invasions, the Church eventually got the privilege of knowing and resolving all civil and criminal cases of their clerics. Consequently, the Ecclesiastical court entered into part of the medieval judicial system, and public force came to its service. During the end of the Carolingian Empire, the judicial power of the church, benefitting from the existing social and political system, was subsequently reinforced ${ }^{68}$. After the fall of the Carolingian Empire, the Church gained much because of the mutated social and political conditions, thus becoming stronger and tending to more judicial procedures. Criminal procedure, observed by the Ecclesiastical magistrature had its legal fundaments in Justinian Law, grown and modified by some elements from disciplinary Ecclesiastical canonic procedure ${ }^{69}$. They were continuous and for longer time, requiring more ways of inquiring for evidence, including tortures for obtaining confessions from the accused and witnesses. A penal or criminal action started when a private citizen accused the author of the infringement of a penal statute, that caused grievance to a personal right or against his family, or even harmful to the public interest. The accuser took the burden of the accusation, having to register it in front of the competent judge. The judge then assisted passively the debate and had limited power for discovering evidence. The accusation therefore had to be proven rigorously by the asserted facts with documents, testimony, and other legal ways pertinent to the cause. In the case of unsuccessful evidence or lack of evidence, the defendant was absolved. Then the accuser was put in the same position as the defendant ex actore fit reus and could be charged with the same penalty as the defendant, as if he would have proven his accusation valid, and could be found guilty ${ }^{70}$.

In the Medieval Ages, during criminal procedures penalties were imposed at the discretion of the judge who used a wood branch in his hand to recognize his authority. The judge conducted the examination, and the sentence was emitted immediately. It was not until 1506 that the first penal code was published in Tyrol. After 1506, criminal cases were held behind closed doors with a secretary that wrote the depositions and sentences ${ }^{71}$. During criminal procedures, application of justice involved finding the rule of law that applied to certain circumstances, and since the beginning of the Holy Roman Empire, the legal system used a varied combination of written and unwritten law, known as legal customs or traditions that were not inferior in rank to the written law ${ }^{72}$. Hence, there are few

\footnotetext{
${ }^{67}$ Astuti, 1968, p. 85.

68 Tammaro, 2018, p. 783.

${ }^{69}$ Tammaro, 2008, pp. 234-235.

70 Ibid., pp. 230-231.

${ }^{71}$ Richebuono, 1999, p. 87.

${ }^{72}$ Wilson, 2017, p. 604.
} 
legal documents available before the 16th century that could be useful in studying the social conditions of the Ladins during the Middle Ages. Notwithstanding, it is evident that Ladins had few liberties and were under the authority of small landlords in a typical feudal system.

The first written legal norm regarding the rights of Ladins dates to circa 1450. In this important document, Ladins from Val di Fassa Valley formally pleaded to the Ecclesiastical Principality of Bressanone/Brixen that preachers and judges needed to know the Ladin language, and also established 18 articles of duties for judges and jurors ${ }^{73}$. In 1513, Ladins from Val Gardena/Gröden pleaded to Bressanone/ Brixen that their priest knew Ladin as expressed in a previous legally binding contract. Later, in 1541, the so-called Livinallongo Statutes were compiled; deriving from Lombard Law they gave a sense of consciousness to the Ladins to constitute their own Ladin group. Consequently, in 1678, during the so-called trial of Selva di Val Gardena/Wolkenstein, it was formally recognized that Ladin was a different language, not used elsewhere and containing foreign sounds.

Regardless, the witch trials of the Ladins, criminal procedures all done in the German language and not in Ladin, are appalling proof of what in our days is considered an extremely inhumane justice system. The first one was during 1546 in Val Badia/Gadertal where a woman was found guilty of witchcraft for giving a potion to another woman to have an abortion. The court found that two twins were born dead and sentenced the accused woman to torture with weight on her feet $^{74}$. Other witch trials from Val di Fassa were held at the Ecclesiastical Principality of Bressanone/Brixen. One of these criminal procedures was in 1573 with 11 accused, including witches and a sorcerer all burned alive after being found guilty. Another witch trial was held there in 1627 with 6 witches accused, including their confessions. After being found guilty, all got decapitated and burned, except 2 that died in prison after cruel tortures ${ }^{75}$.

Generally, the trials of the Ladins were particularly gruesome. In one case, a woman found guilty of killing her sons was sentenced to being buried alive and then spiked through with a pole. Penalties were severe with treason punished by being quartered; the most common death penalty was hanging. Furthermore, those that gave false testimony got three fingers and their tongue cut out. In general, prisons were rare, and in Ladin territories there were none ${ }^{76}$. Women could not stand trial by themselves, disbanded of citizenship on Imperial cities because they could not bear arms. One exception to this rule was in the countryside where a woman could stand for her sick or absent husband in cases and assemblies, even representing themselves as widows. In this regard, as Peter Wilson points out, women of the Holy Roman Empire had more access to power

\footnotetext{
${ }^{73}$ Richebuono, 1992, p. 75.

${ }^{74}$ Ibid., p. 90.

75 Ibid.

${ }^{76}$ Ibid, p. 104.
} 
than in Western Europe during that same period ${ }^{77}$.

Historian Giuseppe Richebuono's research of the Ladins found other distinguishable criminal procedures that give a clear panorama on how justice was executed and how the legal and court system worked. In 1571 in San Cassiano, a man was found dead with his shirt stained in blood. In the garden front of his house, a trail of blood was found, leading to believe that the body was taken there by the men who found the body. The man who found the dead body and who later buried it was accused of the killing. The man accused was also the owner of the land where the killing had taken place and pleaded innocence. The court found that the accused man, together with two servants, took the corpse inside the house, and buried the body after examining that no wounds were found. The court sentence determined that the accused had acted in good faith and was given conditional liberty ${ }^{78}$. In Val Badia/Gadertal a trial dating to 1652 found an elderly woman guilty of killing an 80-year-old man during a public event on a table in the piazza. The killing was done with a bread knife, stabbing it into the brain through the right eye. The killer escaped and was not found ${ }^{79}$. Also in Val Badia/Gadertal in 1677 a man was accused of killing his wife. The wife's body was found without the head. The accused disappeared and was found guilty of the killing. In this case, the court found that the accused man was constantly fighting with his wife and confiscated all his belongings.

\section{Ladins in the context of revolution and wars (1797-1947)}

A young Ladin woman by the name of Katharina Lanz became an important figure in Tyrol during the Napoleonic invasion of 1797 . She was popularly nicknamed as the maid of Spinga because during the Battle of Spinga (1797) together with the Schützen partisan armed militia of Tyrol, took arms against the French with great courage, deciding the victory of battle. The outcome of the battle was important because it gave the first example in Europe of how partisan armed militias could defeat the French Napoleonic troops. After the War of the Third Coalition (18031806) and the Treaty of Pressburg of 1805, Austria ceded Veneto to the Napoleonic Kingdom of Italy and Tyrol to the Bavarians. A few years after, in 1809 the Schützen led by Andreas Hofer liberated Tyrol from French and Bavarian.

Consequently, during the Napoleonic period, specifically between 1810 and 1815 the Ladin Dolomitic territory was broken apart; Val Gardena/Gröden and Val Badia/Gadertal were aggregated to the Kingdom of Bavaria, whereas the Val di Fassa went to the Napoleonic Kingdom of Italy, Department of Alto Adige and Valle d'Ampezzo with Livinallongo were also aggregated to the Italian Kingdom, including the department of Piave. The Napoleonic Wars signal the end of the

\footnotetext{
77 Wilson, 2017, p. 317.

${ }^{78}$ Richebuono, 1999, p. 92.

79 Ibid.
} 
feudal period and the start of modern politics. Ladin unity took a new direction in 1833 with Micurà de Rü, a Ladin priest that advocated the unity of all Ladins, writing books on the grammar of Ladin. Afterward, in 1856 in the city of Innsbruck, Austria, the term Ladin Nations appeared for the first time. During that period the Austrian government characterized ethnic groups because of their language. Nevertheless, Ladin was not codified as an official language yet ${ }^{80}$. Generally speaking, the Austrian authorities did not have a special consideration for the Ladin language in official documents or legal procedures ${ }^{81}$.

Starting in the 20th century, a strong nationalist movement in Austria developed, pushing into public opinion the so-called Pan-Germanism movement with the idea of expanding the German language to Verona and harming the Ladins and their intentions of unity. By contrast, in 1905, the Ladin Union was founded in Innsbruck to unite the Ladins of all Tyrol, promote a unified written language, and obtain official recognition from the Austrian authorities as an ethnic group ${ }^{82}$. After Austria lost World War I, things looked dim for the Ladins. During the war Ladins suffered many deaths, losing a total of 1060 soldiers. Also, with the change of currency a devaluation of $40 \%$ was imposed. The peace negotiations for the Treaty of Saint Germain-en-Laye of 1919 did not take into consideration the Ladins and did not impose on Italy a tutelage of the Ladin minority. Historian Luciana Palla argues how during the aftermath of World War I Ladins were victims of secret treaties, and the principle of nationality was not respected when Ladins were not asked or taken into consideration ${ }^{83}$. An argument used against the Ladins was that they did not have a home country of their own, and that they were not officially recognized as a minority by the Austrian Government.

The transfer from Austria to Italy after the war was not accepted by Ladins because of their political and administrative relations with the Tyrolean world and because Italy was the enemy during the war. In the middle of this political turmoil, Ladins decided to align themselves with the German-speaking politicians of Alto Adige/Südtirol to stop the force of Italians in the region. This alliance was intended to support German identity in Alto Adige/Südtirol and at the same time to reclaim Ladin's ethnicity. On December 5, 1920, 70 representatives from all the Ladin Valleys demanded recognition of Ladins as an ethnic group ${ }^{84}$. During this time the population of Alto Adige/Südtirol was described by the recently named Italian prefect of Trento as a mixed population of Germans, Germanized Italians, pure Ladins, Germanized Ladins, and pure Italians ${ }^{85}$.

Heretofore, the so-called Ladin question was not an important issue in Italian

\footnotetext{
${ }^{80}$ Palla, 1988, p. 167.

${ }^{81}$ Willeit, 2020, p. 24.

82 Ibid., p. 39.

${ }_{83}$ Palla, 1988, p. 160.

${ }^{84}$ Willeit, 2020, p. 27.

${ }^{85}$ Ibid., p. 186.
} 
public opinion. With the implementation of fascism in Italy, a critical point for Ladin identity came forth in Trentino-Alto Adige/Südtirol. In 1921 a quasi-plebiscite established that between $95-100 \%$ of the inhabitants of Ladin territory identified themselves as Ladins. The results were in contradiction with Italian official population numbers during that time ${ }^{86}$. Ladins were recognized in a previous Austrian census in 1851 but had no political participation in the Austro-Hungarian Empire. Their representatives in government were not Ladin, whether Innsbruck or in Vienna, Tyrolians or Trentino tended to their political needs. The reason for this particularity was based on Austrian electoral law that required 40,000 to 100,000 casted votes for a mandate to the Reichsrat (legislative branch) during universal male elections. Ladins in all their villages had only 20,000 voters so they got excluded $^{87}$.

Based on official interest in learning about the Ladins, the Italian authorities started to study and research who were the Ladins. The so-called Ladin question was headed by Carlo Battisti, a Trentino intellectual and writer who started writing before World War I promoting the idea that Alto Adige/Südtirol could be Italianized completely. Battisti worked closely with the fascist regime while publishing several books on Ladins and teaching linguistics at the University of Florence. He firmly believed that Ladins were Italians the same as his countrymen the Trentino and should be inserted into the Kingdom of Italy ${ }^{88}$. Therefore, Battisti's arguments, even though they represent a manifestation of ethnic discrimination, they also depict an official historical perception of Ladins by the fascist Italian authorities. He believed that the so-called Ladin Question was settled early on during the 16th century. As the medieval chronicler from Südtirol Marx Sittich von Wolkenstein wrote that Ladin was a mixed Italian language or rustic Italian; therefore, Battisti based his arguments against unity of the language ${ }^{89}$. Arguments against language unity were also based on Austrian historical sources that sustain differences in Ladin regional dialects ${ }^{90}$. Furthermore, Battisti was convinced about the importance of Latin elements in the Ladin language, because he sustained the colonization of the Ladin territory came from the Roman province of Noricum and not by German speakers as others believed ${ }^{91}$.

Despite that, Italian fascist propaganda did not convince the Ladin population of Italianization because they would be deprived of their language and culture. In reality, the Italian authorities pushed to get rid of the Ladins from their ancestral territory because they saw great economic potential for international tourism

\footnotetext{
${ }^{86}$ Palla, 1997, p. 65.

87 Ibid., p. 60.

${ }^{88}$ Palla, 1988, p. 163.

${ }^{89}$ Battisti, 1937, p. 4.

${ }^{90}$ Ibid., p. 13.

${ }^{91}$ Ibid., p. 14.
} 
and notoriety in the Dolomites Mountains ${ }^{92}$. New infrastructure was developed during World War I connecting different valleys with roads and cable cars. Moreover, for the Ladins the conflict arising a few years later from the so-called South Tyrol Option was a tragedy. Unlike Italian fascism that was violent, the so-called Option for Nazi Germany was a leap into darkness, not only for the abandonment of their homeland but also the translocation to an unknown language and culture ${ }^{93}$.

The Option was ratified after the Hitler-Mussolini meeting in the Alps in 1940, specifically in Brennero/Brenner. Basically, regarding the population of Alto Adige/Südtirol, the two dictators agreed that if the territory could not be ceded to the Nazis, then the people would be relocated to Austria. Thus, from 1939 to 1942 a massive exodus of German speakers and Ladins were transferred to settlements outside Italy. Nevertheless, unofficially, the Italian authorities tried as much as possible to stop or delay the relocation of people from Alto Adige/ Südtirol because of the fear of depopulation in the province. On the other hand, the option was also in the minds of Ladins because they could participate in an electoral process in which they could vote for the first time after World War I in favor of Italian or Austrian citizenship; the latter was annexed to Germany during that time in the so-called Anschluss. The overwhelming majority of the population of Alto Adige/Südtirol favored Adolf Hitler and Nazi propaganda was intense, headed personally by Heinrich Himmler, commander of the Schutzstaffel (SS). In the end, the winner of the South Tyrol Option was German propaganda, with an overwhelmingly majority voting in favor of the Nazi Reich ${ }^{94}$. Specifically, Ladin's votes in favor of the Option were: $32 \%$ in Val Badia/Gadertal, $40 \%$ in Livinallongo del Col di Lana 40\%, and 81\% in Val Gardena/Gröden. Actually, from the 160,000 German-speaking optants that decided to leave Alto Adige/Südtirol, only 7,000 left between 1939 and 1942. Ladin people numbered 7,000 optants with 2,000 partings ${ }^{95}$. The Catholic Church was also caught in the option with $80 \%$ of the clergy voting to keep the Italian Citizenship while the Bishop of the Dioceses of Bressanone/Brixen - Bolzano/Bozen voting for the Reich.

World War II was a very difficult period for the Ladins with the hardest time after the Nazi-German invasion of Italy. The Provinces of Trento, Bolzano/Bozen, and Belluno were annexed into the German Reich as a zone named Alpenvorland (Prealps territory), thus restoring the historical Tyrol borders and establishing an administrative unification and military enlistment of the male population. The commissary of the so-called Alpenvorland was Franz Hofer, a convinced national socialist who was also a right-hand man to Heinrich Himmler. They applied a denationalization campaign of all Italians and Ladins residents in Alto Adige/

\footnotetext{
92 Richebuono, 1992, p. 185.

${ }^{93}$ Willeit, 2020, p. 29.

${ }^{94}$ Willeit, 2020, p. 28.

${ }^{95}$ Ibid.
} 
Südtirol, helped by civilian militias and paramilitary from Alto Adige/Südtirol in the so-called Südtiroler Ordnungsdienst SOD, a paramilitary security department of the Nazis Waffen-SS military regiment. Nazi Socialists started to hunt down voters against the option; Italian military and people suspected of being against the Reich and the local regime and sent them to work camps in Germany. Six hundred Ladin soldiers died after the war. World War II wounded the Ladin people deeply, creating polemics that are still discussed nowadays, with some people favoring the denationalizing of Ladins. Ladins in Alto Adige/Südtirol were politically caught between the Italian and German agendas; and even though, after the war, they aligned with the German-speaking political party in command, the Südtiroler Volkspartei SVP, Ladins are still being used for various political agendas ${ }^{96}$.

Consequently, in 1946 during the Paris Peace Conference for the Treaty of Paris of 1947, the Südtiroler Volkspartei SVP was the only organization that defended the rights of Ladins as an ethnic group, even though Ladins were not included in the so-called Gruber-De Gasperi Agreement of 1946. It should be noted that Alcide De Gasperi, the Italian Prime Minister during the agreement was a German-speaking Trentino that firmly believed Ladins were Italians and not an ethnic minority ${ }^{97}$. After the war, several public manifestations from Ladins were requesting the legal right to self-determination, political autonomy, and the official recognition of their ethnic group ${ }^{98}$. In the aftermath of the Treaty of Paris of 1947, an autonomous region was recognized with the Constitution (1948) but it caused disappointment within the Ladin political leaders in part because the Dolomite Valleys of Ampezzo and Livinallongo del Col di Lana were excluded from the Trentino-Alto Adige/Südtirol Region. Interestingly enough, those same Ladin communities voted in a 2007 referendum overwhelmingly, 80\% preferring to leave the Veneto Region and in favor of incorporation into Trentino-Alto Adige/ Südtirol. Soon after the Constitution was enforced on January 1, 1948 the socalled Autonomy Statute of Trentino-Alto Adige Legge Costituzionale 26 febbraio 1948 , n. 5 was approved, containing several articles that had to with legal rights for the Ladins.

\section{Constitutional Reforms and Autonomy for Ladins in Trentino-Alto-Adige/} Südtirol

During the 1970's the difficult situation in Alto Adige/Südtirol with the German speaking "Austrians" in Italy had long resented their subjection, turning to many political demonstrations, assaults, and even bomb attacks. This problem was resolved by the creation of an autonomous bilingual region ${ }^{99}$. As for the Ladin

\footnotetext{
${ }^{96}$ Ibid, 30.

${ }^{97}$ Richebuono, 1992, p. 190.

${ }_{98}$ Palla, 1988, p. 181.

99 Judt, 2010, p. 465.
} 
minority, that remained peaceful during the political turmoil of the period, significant reforms were carried out, starting with the so-called Second Autonomy Statute of Trentino-Alto Adige/Südtirol Decreto del Presidente della Repubblica 31 agosto 1972, n. 670, where the rights of Ladins have been the issue of a series of constitutional reforms made possible through state-approved laws, provincial legal norms, and decisions from the Constitutional Court. This legal apparatus serves as the foundation for the administration, provincial legislation, politics, education, culture, and some court procedures of the Trentino-Alto Adige/Südtirol autonomous province of Italy. Between 1948 until 2018, in Alto Adige/Südtirol, more than 100 laws have been implemented that deal with the rights of Ladins. In this article I will only discuss some of the laws that in my opinion pose potential constitutional challenges.

With the Second Autonomy Statute the right to use the German language in the public administration and judicial offices was established as fundamental Constitutional right; therefore, the Italian and German languages became equal, based on Article 99 of Decreto del Presidente della Repubblica 31 agosto 1972, n. 670. (D.P.R. 670/1972) that establishes:

In the region, the German language is equated with the Italian language which is the official language of the State. The Italian language is the text in the acts of a legislative nature and in the cases in which the drafting of bilinguals is envisaged by this Statute.

Even though Ladin was left out in the wording of Article 99 (D.P.R. 670/1972), it has other articles that specifically give legal rights to Ladins: Article 15 establishes Ladin as the language used in elementary schools and its administration in Ladin territory; Article 54 bis guarantees political representation of Ladins in Regional and Provincial organisms; Article 77 bis creates a system of government jobs destined to persons from the Ladin Minority; Article 83 establishes the right of Ladins to legally challenge the validity of state laws that violate their minority rights; and, Article 87 safeguards Ladin culture, popular traditions and the toponomastic of places in Ladin territory. Nonetheless, some small inequalities are evident in the Statute (D.P.R. 670/1972); for example, the fact that Ladins cannot be employed in other non-Ladin municipalities because according to the percentage of proportional representation they are few in population ${ }^{100}$.

An important issue with Ladins in Trentino-Alto Adige/Südtirol has been the unification or standardization of the Ladin language in the Dolomites Mountains with many attempts with that objective being unsuccessfull ${ }^{101}$. Adding to this challenge has been the disadvantage that Ladins do not have a nation to refer to as their own in a national or international context, so Ladins have looked for trans frontier cooperation and help with other Ladin minorities forming political affini-

\footnotetext{
100 Peterlini, 1997, p. 193.

${ }^{101}$ Pescosta, 2010, p. 536.
} 
ties $^{102}$. Politician and author Carlo Willeit points out that Ladins have been heard by the Italian Parliament and the Government, including the President of the Republic; nonetheless, it has been impossible to get Ladins in the institutions that create laws ${ }^{103}$. In other words, an absence of representation in the democratic process. A recent example of this, is seen in the State Law that excludes Ladins from the Provincial Administrative Court of Appels TAR Tribunale Amministrativo Regionale (Decreto legislativo 19 maggio 2017, n. 77). The issue revolves around Article 6 of the original law creating the Administrative Court that established the number of judges to be either from the German or Italian groups, omitting Ladins (Decreto del Presidente della Reppublica 6 aprile 1984, 426). This legal issue, regarding the composition of judges in administrative court can be interpreted as inconsistent with Art. 6 of the Constitution that reads: «The Republic safeguards linguistic minorities by means of appropriate measures». Consequently, Ladins find themselves in a particular legal situation from a constitutional point of view, and it could be demonstrated by their modern history how they surpassed as a minority within a minority, meaning a minority in alliance with the German-speaking group of Alto Adige/Südtirol. In a practical sense, all measures that have to do with provincial autonomy and Ladins are dependent on the German-speaking population of Alto Adige/Südtirol with shared legal rights and responsibilities. One popular affirmation in Alto Adige/Südtirol is that South Tyrolian Germans have adopted Ladins ${ }^{104}$.

In the case of criminal judicial procedures in Alto Adige/Süditirol, a Ladin person has the right to choose whether to have their trial either in German or Italian, but not in Ladin as expressed in Decreto del Presidente della Reppublica 15 luglio 1988 , n. 574. Furthermore, criminal cases raising legal issues and controversies with this law (D.P.R. 574/1988) fall under the jurisdiction of Court of Bolzano/ Bozen, and the Court of Appeals of Trento. This has important significance in criminal procedures because all court notifications and police reports that are received by the defendant in another language different than the one decided on, either Italian or German, are considered invalid until formally translated. Therefore, Article 8.1 (D.P.R. 574/1988) states that:

Interested parties may raise the objection of nullity of administrative acts or measures issued by the bodies, offices and concessionaires indicated in article 1 , as well as communications or notifications from them, which are formulated in contrast with the provisions of article 7.

Whereas, requiring the defendant to plea to the court the incorrect use of the language, German or Italian, for the invalidity of all criminal process against him. This plea surely would be to the benefit of the defendant in gaining time during

\footnotetext{
${ }^{102}$ Hilpold, 2006, p. 25.

${ }^{103}$ Willeit, 2020, p. 30.

${ }^{104}$ Hilpold, 2006, p. 32.
} 
his criminal procedure, as recognized in Article 8.5 (D.P.R. 574/1988) that states: "The objection of nullity suspends all the effects of the act». Furthermore, Article 18 bis. (D.P.R. 574/1988) specifically refers to criminal procedures, whereas:

Failure to comply with the provisions of articles 14, paragraph 3,15, paragraphs 4 and 5,16 , paragraph 7 , is prescribed under penalty of nullity, pursuant to article 181 of the criminal procedure code. The declaration of invalidity involves the obligation of translation, without regression of the procedure to the state and degree in which the null act was carried out.

Therefore, imposing to the court the obligation of starting over the criminal investigation and any court procedures held before the formal objection. It is not an uncommon occurrence in the Court of Bolzano/Bozen cases where defendants are wrongly presumed being from an incorrect linguistic group. For example, from the Italian linguistic group based on an Italian last name, therefore having the procedural notifications arriving to a defendant that is from the German linguistic group. These important legal dispositions, make Alto Adige/Südtirol a distinct court jurisdiction in Italy.

It should be also noted that Article 109, second paragraph of the Italian Code of Criminal Procedure, as amended, Decreto del Presidente della Repubblica 22 settembre 1988, n. 447 clearly states that:

Before the judicial authority with first-instance or appeal competence over a territory where a recognized linguistic minority is settled, the Italian citizen belonging to such minority shall be questioned or examined, upon his request, in his mother tongue and the related record shall also be drafted in that language.

This specific reference to linguistic minorities is only included in the Code of Criminal Procedure but not in the Code of Civil Procedure or the Code of Administrative Procedure. Thus leaving an absence of the rule of law for other judicial procedures that are not criminal. Nonetheless, Article 122, second paragraph, of the Code of Civil Procedure, Regio Decreto 20 ottobre 1940, n. 1443, as amended, does allow for a translator, but as mentioned earlier it is silent with regards to linguistic minorities: "When a person needs to testify and does not understand Italian the Court may designate and interpreter». Therefore, it is evident that the issue of omitting Italian linguistic minorities from both the civil and administrative procedural rules potentially contradicts Article 111, first paragraph, of the Constitution that reads: "Jurisdiction is implemented through due process regulated by law».

As an exception, judicial procedures can be held in Ladin only in the Giudice di pace (lower court) for small claims and misdemeanors appertaining to jurisdictions where Ladins live. Specifically, in the Giudice di pace located in cities of Bressanone/Brixen, Bolzano/Bozen, and Brunico/Bruneck. Nonetheless, virtually all cases where Ladins have this jurisdictional right are conducted either in Italian or German. One reason for this is the lack of both civil and penal procedural rules 
and codes of law that makes it difficult for Ladin lawyers and judges to conduct a judicial procedure in Ladin. Even though, Article 32, Fourth Paragraph, (D.P.R. 574/1988) establishes this procedural right it is hardly enforced:

The interested party has the right to be examined and questioned, in the trials taking place in the province of Bolzano, in his mother tongue with the help of the interpreter, both in the Italian and in the German language process. For the purposes of applying Chapter IV of this decree, the aforementioned interested party has the right to use the German language instead of the Italian one. The use of the Ladin language is permitted in proceedings before the Giudice di pace (lower court) competent for the territories of the Ladin localities in the province of Bolzano. In the assignment of the office of Giudice di pace (lower court) competent for the territories of the Ladin localities in the province of Bolzano, absolute priority must be given to those who are familiar with the Ladin language ascertained pursuant to the decree of the President of the Republic of 26 July 1976, no. 752. For these proceedings before the Giudice di pace (lower court), the Trentino-Alto Adige region ensures the necessary organizational and financial interventions.

Therefore, because of the absence of Ladin judicial procedures conducted under the jurisdiction of the Giudice di pace (lower court), Article 32, Fourth Paragraph, (D.P.R. 574/1988) has become a procedural rule in disuse, albeit with a symbolic and political importance for the Ladins, and with the practical effect of giving priority in the appointment of Ladins to hold jobs as Giudice di pace in those jurisdictions. A reminder of their resilience in obtaining official recognition of their language and the potential for further legal development.

In comparison, Ladins residing in the Trentino Province of the Trentino-Alto Adige/Südtirol Region have the right to use Ladin as their official language in municipalities that are historically Ladin, specifically in public documents, including their identification cards, as established under Article 1 of the Decreto legis/ativo 4 aprile 2006, n. 178. Moreover, under Article 2 of the so-called Autonomy Statue of Trentino-Alto Adige, as amended (L. costituzionale 5/1948) Ladin is protected in the Province of Trento as an official language: "In the region personal equality is recognized to citizens, whatever linguistic group they belong to, safeguarding ethnic and cultural characteristics, respectively». Despite that, Ladins living there have not exercised this right because of a lack of political participation and control of local and national political parties. Another important factor has been the lack of roads connecting the province of Trento with Alto Adige/Südtirol, contributing negatively in unifying Ladin language public policy. With this aim in mind, several Ladin leaders suggest that local Ladin municipalities should take the task of gaining political ground by submitting legal opinions and legal memoranda to the provincial government as well as legislation proposals for constitutional and administrative issues that closely regard the needed perspectives of the Ladin minority ${ }^{105}$. In contrast, Ladins in Alto Adige/Südtirol have made important

${ }^{105}$ Willeit, 2020, p. 79. 
leaps from those in Trento, including: 1- The right for economic contributions for cultural and social associations, 2- Their own educational system, 3- Representation in the Provincial Council of Bolzano/Bozen, 4- Public jobs destined to Ladins, and 5- Legal legitimation to represent themselves and to promote judicial review giving tutelage to Ladin minority rights. Also, in Alto Adige/Südtirol Ladins are admitted to the vice presidency of the Provincial Council, and can eventually reach the presidency, including the right to be part of the Provincial Assembly of Bolzano/Bozen.

Accordingly, Ladins have also taken their pleas to the Italian highest court. An important Ladin legal issue came to the Constitutional Court regarding rights under Article 56 of Decreto del Presidente della Repubblica 31 agosto 1972, n. 670. Specifically, Article 56, First Paragraph (D.P.R. 670/1972) states that:

If a bill of law is deemed to be detrimental to the equality of rights between citizens of different linguistic groups or to the ethnic and cultural characteristics of the groups themselves, the majority of the councilors of a linguistic group in the regional or provincial council of Bolzano may request to vote by linguistic groups.

Arguments were presented to the Constitutional Court by a Ladin elected official in the Provincial government of Alto Adige/Südtirol, asking for judicial revision for an approved law that was detrimental to equality of rights of the Ladin language minority. Therefore, the Court interpreted that in the case presented by one Ladin elected official in the Regional Council or in the Provincial Council of Alto Adige/Südtirol there is legal standing to ask the highest court for judicial review if a specific law is harmful to the Ladin Minority, within 30 days of its publication, Corte Costituzionale, Sentenza 356/1998.

More recently the Constitutional Court decided on a case in which Ladin was used exclusively to name the new town of San Giovanni/San Jèn in the province of Trento, Corte Costituzionale, Sentenza 210/2018. The Court ruled that the Ladin name San Jèn could not be used alone, requiring the official bilingual name of San Giovanni/San Jèn. Toponymy has a controversial history in Trentino-Alto Adige/Südtirol, initiated with fascism and the so-called Italianization of Alto Adige that aimed at eradicating the Ladin and German languages. Specifically with the Regio Decreto 27 aprile 1923, n. 99 that officially changed all the German names of towns in Trentino-Alto Adige/Südtirol to Italian. Notwithstanding, nowadays things have changed for the better. A subsequent case from the Constitutional Court, Corte Costituzionale, Ordinanza, 190/2019 recognized that bilingual toponymy is following: «the principle of equal treatment of ethnic groups and safeguards the respective ethical and cultural characteristics». In both court cases, the Constitutional Court upheld the exception that Italian is not the only official language in Trentino-Alto Adige/Südtirol, justifying it on the concessions of bilingualism and trilingualism made by the Second Autonomy Statute, as amended (D.P.R. 670/1972). 


\section{Conclusions}

Ladins in Trentino-Alto Adige/Südtirol have an important historiography that document with primary sources their trajectory as an ethnic minority through their legal history in several legislations, judicial processes, and political arenas. Historians have published several books in German, Italian, and Ladin that commit to this fact, adding to this an interest, first by the Austrian and the Italian governments, to understand who were the Ladins and their origins, in order to effectively govern them. It is also a reality that historical publications in English are scarce and incomplete. Furthermore, adequate legal-historical context of Ladin history is insubstantial. Therefore, I am confident that the present legal-historical analysis of Ladin history would benefit other research in the future. Specifically, it was paramount to the better understanding of Ladin legal resilience in the context of Lombard and Carolingian Law during the Middle Ages. However, there is still more legal-historical research to be done for the one-thousand-year period Longue durée during the Holy Roman Empire; it is a period that left an abundant written track of judicial procedures and several legislations dealing with Ladins in the German language that has not yet been properly documented and critically analyzed.

In addition, the laws that have induced Ladin gaining political liberties and civil rights are noteworthy. Nevertheless, a critical legal analysis of the legal apparatus of Ladin rights in Trentino-Alto Adige/Südtirol is needed. Therefore, I am also confident that presenting the citations of some of the laws and judicial decisions that I believe pose legal controversies can be useful for future legal research and analysis. In the context of International Law Ladins as a multi-national European minority are in a particular conjecture nowadays that was unheard during their period under Austrian rule, in the Treaty of Saint Germain-en-Laye of 1919 that ceded Trentino Alto-Adige /Südtirol to Italy, and subsequently under Italian Fascism.

In that sense, Ladins have historically persevered for their legal rights regarding the use of the Ladin language. Even though in the 19th century language was recognized as a valid criterion for being considered an ethnic group, Ladins were unable to reach this point because of their small population numbers, compared with other linguistic groups in Europe. Nowadays, there is no controversy on their legal status because Ladins are recognized as a linguistic and ethnic minority, under the protection of Article 6 of the Constitution: "The Republic safeguards linguistic minorities by means of appropriate measures». Not only are Ladins constitutionally protected, but they also enjoy rights under International Law. Article 27 of the UN General Assembly, International Covenant on Civil and Political Rights, 16 December 1966 states that:

In those States in which ethnic, religious or linguistic minorities exist, persons belonging to such minorities shall not be denied the right, in community with the 
other members of their group, to enjoy their own culture, to profess and practice their own religion, or to use their own language.

Moreover, the UN General Assembly, Declaration on the Rights of Persons Belonging to National or Ethnic, Religious and Linguistic Minorities., 3 February 1992 sets the fundamental standards and guidelines to states adopting legislative and other legal measures to secure and guarantee the rights of persons that belong to minorities. The Ladin Minority also has legal rights under European Union Law, specifically Article 14 of the Convention for the Protection of Human Rights and Fundamental Freedoms, Rome 4.XI.1950, Article 14 reads:

The enjoyment of the rights and freedoms set forth in this Convention shall be secured without discrimination on any ground such as sex, race, colour, language, religion, political or other opinion, national or social origin, association with a national minority, property, birth or other status.

Therefore, it is evident that Ladins have come a great way forward in their claim for rights regarding their minority status. Nevertheless, there is consensus among Ladin jurists and intellectuals that many legal challenges need to be addressed. Ladin unity and a standardized language have been a historical issue that unfortunately Ladins have tried to resolve without success. Also, political equality with other language groups in Trentino-Alto Adige/Südtirol has not been met. The future may hold many surprises for the Ladins. Surely their resilience and perseverance will triumph over these and other obstacles for justice and equality, as they have done in the past, surviving for centuries with their ethnic identity.

\section{Bibliography}

Astuti G., 1968: Lezioni di storia del diritto italiano: Le fonti età Romano-Barbarica, Padova, CEDAM

Barnwell P.S., 2000: Jurists and Kings: Law and Custom in the Late Roman and Early Medieval West, in "Past \& Present", August No. 168, pp. 6-29

Battisti C., 1937: Storia della questione ladina, Firenze, F. Le Monnier

Belardi W., 2003: Breve storia della lingua e della letteratura ladina, Bolzano, Istitut Ladin Micurà de Ru

Bernardi R., 2002: La storia della letteratura ladina delle Dolomiti e la letteratura ladina oggi, in "Quaderns d' Italia ", 7, pp. 41-61

Calliari F., 1991: La minoranza ladino-dolomitica: costituzione, statuto d'autonomia, leggi regionali e provinciali, Rimini, Maggioli Editore

Coleman V.R., 1974: Reason and Unreason in Early Medieval Law, in "The Journal of Interdisciplinary History", Spring Vol. 4, No. 4, pp. 571-591 
Complojer F., 1990: Disparità di trattamento accusate dai Ladini viventi nella Regione Trentino Alto Adige con particolare riguardo alle istruzioni legislative della regione e delle due province autonome, in "Ladinia", XIV, pp. 305-324

Complojer F., 1991: Disparità di trattamento accusate dai Ladini viventi nella Regione Trentino Alto Adige nei rapporti con gli uffici pubblici nel settore culturale e riguardo alla salvaguardia della integrità e stabilità della minoranza, in "Ladinia", XV, pp. 273-287

Davis R. J., 2005: Charlemagne's Practice of Empire, Cambridge, Cambridge University Press

De Biasi M., 2008: I/ sudtirolo della contea alla Heimat, Bolzano, Praxis

Dean T., 1997: Marriage and Mutilation in Late Medieval Italy, in "Past \& Present", 157, pp. 3-36

Diurni G., 2011: Aspirazioni di giuridicità del medioevo: lezioni di storia del diritto italiano, Torino, Giappichelli

Filippone V., 1942: I ladini dolomitici, Bolzano, Atesia Augusta

Galgani B., 2012: Diritto probatorio e successione di leggi nel tempo. Tempus regit actum?, Torino, Giappichelli

Garipzanov l., 2008: The symbolic language of authority in the Carolingian world (c. 751-877), Leiden, Brill

Gatter C., 1994: In lotta contro Roma: cittadini, minoranze e autonomie in Italia, Bolzano, Praxis 3

H.S.O., 1951: Ratien im frühen Mittelalter by Elizabeth Meyer-Marthaler, in "The English Historical Review", Vol. 66, No. 258, pp. 129-130

Hartung von Hartungen C., 2002: A brief contemporary history of Alto Adige/ Südtirol (1918-2002), Bolzano, Provincia autonoma di Bolzano

Hilpold P., 2006: I ladini una minoranza nella minoranza, Bolzano, Athesia

Hodgkin T., 1895: Italy and Her Invaders: 600-744. The Lombard Kingdom, Book VIII, Volume VI, Oxford, Clarendon Press

Judt T., 2010, Postwar: A History of Europe Since 1945, London, Vintage Books

Kustatscher E., 2010: Passaggi e prospettive: lineamenti di storia locale: I'area tirolese della preistoria al tardo medioevo, Bolzano, Athesia

Maclean S., 2009: Insinuation, Censorship and the Struggle for Late Carolingian Lotharingia in Regino of Prüm's Chronicle, in "The English Historical Review", 2009, Vol. 124. No. 506, pp. 1-28

Palla L., 1988: Processi di tedeschizzazione e di italianizzazione dei ladini dolomiti nel periodo della grande guerra e dell'annessione all' Italia, in "Ladinia", XII, pp. 159-189

Palla L., 1997: I Ladini fra Austria e Italia: vicende storico-politiche di una minoranza nel corso del Novecento, in "Ladinia", XXI, pp. 59-71 
Pene Vidari G. S., 2009: Elementi di storia del diritto medievale e moderno, Torino, Giappichelli

Pescosta W., 2010: Storia dei Ladini delle Dolomiti, Bolzano, Istitut Ladin Micurà de Rü

Peterlini O., 1997: Autonomy and the protection of ethnic minorities in TrentinoSouth Tyrol, Bolzano, Regional Parliament Trentino-South Tyrol

Richebuono G., 1992: Breve storia dei ladini dolomitici, San Martin de Tor, Istitut Cultura Ladin Micurá de Tor

Richenbuono G., 1999: Processi criminali dal 1493 alla fine del 1600, in "Ladinia", XXIII, pp. 85-94

Richebuono G., 2000-2001: Stralci da alcuni documenti degli archivi di Innsbruck riguardanti la Ladinia, in "Ladinia", XXIV-XXV, pp. 47-50

Tammaro C., 2008: L'atto introduttivo (denuntiatio) e la fase preliminare del processo penale canonico in epoca basso-medievale: rilievi storico-giuridici, in "Ius Canonicum", XLVIII, pp. 227-245

Tammaro C., 2018: L'instruction probatoria nel processo penale mediavale: osservazioni canoniche sull' ammissione e l'assunzione dei mezzi di prova nei secoli XIII e XIV, in "Ius Canonicum", Vol. 58, pp. 781-809

Toch M., 1986: Asking the Way and Telling the Law: Speech in Medieval Germany, in "The Journal of Interdisciplinary History", Vol. 16, No. 4, pp. 667-682

Willeit C., 2020: Ladini: la minoranza ladina sellana-ampezzana, Bolzano, Pentagon

Wilson P., 2017: The Holy Roman Empire: A Thousand Years of Europe's History, London, Penguin Books

\section{Laws and normative sources}

Costituzione della Repubblica Italiana

Convention for the Protection of Human Rights and Fundamental Freedoms, Rome 4.XI.1950

Corte Costituzionale, Sentenza 261/1995

Corte Costituzionale, Sentenza 356/1998

Corte Costituzionale, Sentenza 210/2018

Corte Costituzionale, Ordinanza 190/2019

Decreto legislativo 4 aprile 2006, n. 178, "Norme di attuazione dello statuto speciale della regione Trentino-Alto Adige/Südtirol, concernente modifiche al decreto legislativo 16 dicembre 1993, n. 592, in materia di tutela della popolazione di lingua ladina in provincia di Trento"

Decreto legislativo 19 maggio 2017, n. 77, "Norme di attuazione dello statuto 
speciale per la regione Trentino-Alto Adige recante modifiche ed integrazioni al decreto del Presidente della Repubblica 6 aprile 1984, n. 426, concernenti le modalità di nomina e la composizione del tribunale regionale di giustizia amministrativa- sezione autonoma di Bolzano"

Decreto del Presidente della Repubblica 31 agosto 1972, n. 670, as amended, "Testo unificato delle leggi sullo statuto speciale per il Trentino Alto Adige"

Decreto del Presidente della Repubblica 6 aprile 1984, n. 426, as amended, "Norme di attuazione dello statuto speciale per la ragione Trentino-Alto Adige concernenti istituzione del tribunale amministrativo regionale di Trento e della sezione autonoma di Bolzano"

Decreto del Presidente della Repubblica 15 luglio 1988, n. 574, as amended, "Norme di attuazione dello Statuto speciale per la regione Trentino-Alto Adige in materia di uso della lingua tedesca e della lingua ladina nei rapporti con la pubblica amministrazione e nei procedimenti giudiziari"

Decreto del Presidente della Repubblica 22 settembre 1988, n. 447, as amended, "Codice di procedura penale"

Legge costituzionale 26 febbraio 1948, n. 5, as amended, "Statuto speciale per il Trentino Alto Adige"

Regio Decreto 27 aprile 1923, n. 99

Regio Decreto 20 ottobre 1940, n. 1443, as amended, "Codice di procedura civile"

UN General Assembly, International Covenant on Civil and Political Rights, 16 December 1966

UN General Assembly, Declaration on the Rights of Persons Belonging to National or Ethnic, Religious and Linguistic Minorities., 3 February 1992 